\title{
CORRIGENDUM
}

\section{Elder mistreatment, ageism, and human rights-CORRIGENDUM}

Simon Biggs and Irja Haapala

Published online by Cambridge University Press 08 February 2013

doi: $10.1017 /$ S1041610212002372

The authors regret that the affiliation for the second author, Irja Haapala is incorrect:

School of Applied Educational Sciences and Teacher Education, University of Eastern Finland, Savonlinna, Finland

Currently a Visiting Research Fellow, National Ageing Research Institute, Melbourne, Victoria, Australia

The correct affiliation is:

Faculty of Life and Social Sciences, Swinburne University of Technology, POB 218, Hawthorn, Victoria 3122, Australia

Currently on secondment from School of Applied Educational Sciences and Teacher Education, University of Eastern Finland, Savonlinna, Finland

Currently a Visiting Research Fellow, National Ageing Research Institute, Melbourne, Victoria, Australia

\section{Reference}

Biggs, S. and Haapala, I. (2013) Elder mistreatment, ageism, and human rights. International Psychogeriatrics, published online 8 February 2013, doi:10.1017/S1041610212002372. 